\title{
O Estado em Edith Stein: uma reflexão onto-teológico-política da "comunidade estatal" na contemporaneidade
}

\author{
Orientador: Paulo Fernando Carneiro de Andrade \\ Doutorando: Everaldo dos Santos Mendes \\ Área de Concentração: Teologia Sistemático-Pastoral \\ Linha de Pesquisa: Religião e Modernidade \\ Projeto de Pesquisa: Crise da Modernidade e Teologia Latino Americana
}

Esta pesquisa reflete sobre a questão do fundamento - onto-teológico-político - do Estado em Edith Stein na contemporaneidade, sob a perspectiva da Teologia Latino-Americana. Partindo do método fenomenológico-historiobiográfico, optamos por realizar uma pesquisa qualitativa de caráter bibliográfico, que reuniu a história pessoal e os escritos de Edith Stein, em diálogo com seus mestres e estudos histórico-críticos do Estado na contemporaneidade. Para tanto, ordenamos, comparamos e examinamos, com recurso à poética sertaneja. Para Edith Stein, a pessoa humana - o eu consciente e livre - é composta por um corpo vivente [Leibgestalt], uma psique [Seele] e um espírito [Geist]. No seio do mundo, o eu consciente e livre vive de modo particular, mas ligado a uma estrutura universal. Por meio do ato sui generis da entropatia [Einfühlung], vivencia o "eu", o "tu" - via de acesso ao "ser eterno" - e o "nós". Na base do Estado, identificamos três modos de vida associativa: massa, sociedade [Gesellschaft] e comunidade [Gemeinschaft]. Na visão orgânica do Estado, deparamo-nos com os aspectos espiritual [soberania], psíquico [povo] e corpóreo [território], o que nos fez saber que o Estado necessita de um território do mesmo modo que a pessoa humana carece de um corpo para viver. Para fins do seu fundamento onto-teológico-político, o Estado reclama para si uma comunidade estatal, por ser o único modo de vida associativa capaz de abarcar a pessoa humana na sua totalidade existencial. Intersubjetivamente, a comunidade estatal insere-se na humanidade. Entropa- 
ticamente, a Igreja pretende ser a comunidade que abarca a comunidade estatal e toda a humanidade. Nos escritos de Edith Stein, a soberania - condicio sine qua non - está para o Estado assim como a liberdade está para a pessoa humana.

Palavras-chave: Edith Stein. Pessoa humana. Experiência cristã de Deus. Vida associativa. Comunidade estatal. 